\title{
Making a humanities town: knowledge-infused clusters, civic entrepreneurship and civil society in local innovation systems
}

Henry Etzkowitz

Correspondence: h.etzko@ googlemail.com

International Triple Helix Institute, Palo Alto, USA

\begin{abstract}
Knowledge-infused clusters, involving governmental and university, as well as firm actors are the epitome of contemporary economic development strategy. The role of Southern Oregon University (SOU) in the inception of the Oregon Shakespeare Festival (OSF) gives rise to a model for education-focused universities to play a significant role in local economic development through creation of cultural clusters from existing knowledge. Since the arts as well as the sciences provide a base for knowledge-based clusters, all universities have the potential to contribute to economic and social development. In a traditional conception of academic entrepreneurship, a research base may be a pre-requisite to creating spin-offs. However, if we expand entrepreneurship into a broader conception to map its various forms of commercial, social, cultural and civic entrepreneurship, a teaching university may also be the source of new economic activity. The convergence of entrepreneurship, triple helix, cluster and Civil Society frameworks, exemplified by the Ashland case, may provide a model as instructive as Silicon Valley, to seekers of a general theory and practice of regional innovation. A vibrant Civil Society that provides a fertile seedbed for civic entrepreneurship and triple helix interactions enhances clustering.
\end{abstract}

Keywords: Civic entrepreneurship; Civil Society; Triple Helix; Cultural cluster; Etrepreneurial university 


\section{Resumen}

Los clústeres de conocimiento, que integran gobierno, universidad y actores empresariales, son el epítome de las estrategias contemporáneas de desarrollo económico. La labor de la Southern Oregon University (SOU) en la creación del Festival Shakespeare de Oregón (OSF) es un modelo para que las universidades centradas en la educación asuman una función significativa en el desarrollo económico local a través de la creación de clústeres culturales basados en conocimiento pre-existente. Dado que tanto las artes como las ciencias constituyen los cimientos de la existencia de clústeres basados en conocimiento, todas las universidades disponen del potencial para contribuir al desarrollo económico y social. Según la concepción tradicional de emprendimiento académico, la investigación es el prerrequisito para la creación de spin-offs. Sin embargo, si se amplía el emprendimiento a una concepción más amplia en la que tengan cabida diversas formas de emprendimiento comercial, social, cultural y cívico, una universidad centrada en la formación podrá ser también la fuente de una nueva actividad económica. La convergencia entre los marcos de trabajo del emprendimiento, la triple hélice, los clústeres y la sociedad civil, ejemplificada en el caso de Ashland, constituye un modelo tan instructivo como el de Silicon Valley para quienes buscan una teoría y práctica generales para la innovación regional. Una sociedad civil dinámica que produzca un terreno fértil para el emprendimiento social y las interacciones de triple hélice mejorará el clustering.

\section{Résumé}

Les clusters fondés sur la connaissance, impliquant l'université, le gouvernement, et les entreprises sont l'épitomé des stratégies contemporaines de développement économique. Le rôle de la Southern Oregon University (SOU) dans la création de l'Oregon Shakespeare Festival (OSF) donne lieu à un modèle où des universités axées sur l'éducation jouent un rôle important dans le développement économique local par la création de clusters culturels à partir des connaissances existantes. Étant donné que les arts, tout comme les sciences offrent une base pour des clusters fondées sur la connaissance, toutes les universités ont le potentiel pour contribuer au développement économique et social. Dans une conception traditionnelle de l'entreprenariat universitaire, une base de recherche peut être une condition préalable à la création d'entreprises spin-off. Toutefois, si nous élargissons l'entrepreneuriat à une conception plus large en vue de cartographier les différentes formes d'entrepreneuriat commercial, social, culturel et civique, une université d'enseignement peut aussi être la source d'une nouvelle activité économique. La convergence des différents cadres de l'entrepreneuriat, de la triple hélice, des clusters et de la société civile, exemplifiée par le cas d'Ashland, peut fournir un modèle aussi instructif que celui de la Silicon Valley, à ceux qui recherchent une théorie générale et une pratique d'innovation régionale. Une société civile dynamique qui fournit un terreau fertile pour l'entrepreneuriat social et des interactions de triple hélice améliore le clustering. 


\section{摘要}

一个充满活力的公民社会有利于公民创业和三螺旋相互作用。在美国俄勒冈州 莎士比亚戏剧节 (OSF) 诞生之初, 南俄勒冈大学 (SOU) 从现有知识出发创造文化产 业集群, 引发出教学型大学在地方经济发展中起重要作用的一个模式。既然艺术 及科学能为以知识为基础的产业集群提供基础, 那么所有的大学都具有潜力促进 经济和社会发展。在学术创业的传统观念中, 研究基础可能是创建衍生公司的先 决条件。然而, 如果我们把创业概念扩大为更广泛地包括各种形式的商业、社 会、文化和公民创业, 那么教学型大学也可以是新经济活动的源头。创业、三螺 旋、产业集群和公民社会框架的融合, 以阿什兰案例为证, 可为探寻区域创新一 般理论与实践的人们提供一个像硅谷那样有启发性的模式。

\section{Абстракт}

Высокотехнологичные кластеры, в деятельность которых вовлечены государство и университеты, а также представители бизнеса, представляют собой пример реализации современной стратегии экономического развития. Университет Южного Орегона (Southern Oregon University) принимает активное участие в организации Шекспировского Фестиваля в Орегоне (Oregon Shakespeare Festival), реализуя тем самым модель деятельности образовательных университетов, которые играют значительную роль в локальном экономическом развитии путем создания культурных кластеров на основании существующих знаний.

Поскольку искусство, равно как и наука, совместно формируют базу для технологичных кластеров, все университеты имеют потенциал к участию в экономическом и социальном развитии. В рамках традиционной концепции академического предпринимательства, наличие исследовательской базы может являться предпосылкой к созданию спин-офф компаний. В то же время, в рамках более широкого подхода к идеям предпринимательства, включающего различные формы коммерческого, социального, культурного и гражданского предпринимательства, образовательные университеты могут также выступать в роли нового источника экономической активности.

Взаимопроникновение концепций предпринимательства, тройной спирали, кластера и гражданского общества, подтвержденное примером г.Ашленд, штат Орегон, может послужить основой модели, сопоставимой по полезности с опытом Силиконовой долины, которая будет востребована среди исследователей теории и практики региональных инноваций. Динамичное гражданское общество обеспечивает плодородную почву для гражданского предпринимательства и формирования тройной спирали, усиливая кластеризацию. 


\section{Resumo}

Cluster baseados conhecimento, envolvendo como atores o governo e a universidade, bem como as empresas são a síntese da estratégia de desenvolvimento econômico contemporâneo. O papel da Southern Oregon University (SOU), na criação do Oregon Shakespeare Festival (OSF) dá origem a um modelo de ensino com foco no papel relevante que as universidades desempenham no desenvolvimento econômico local, através da criação de clusters culturais a partir do conhecimento já existente. Na medida em que as artes, bem como as ciências oferecem uma base para clusters baseados no conhecimento, todas as universidades têm o potencial de contribuir para o desenvolvimento econômico e social. Em uma concepção tradicional do empreendedorismo acadêmico, uma base de pesquisa pode ser um pré-requisito para a criação de spin-offs. No entanto, se nós expandirmos o empreendedorismo para uma concepção mais ampla para mapear as suas diversas formas de empreendedorismo comercial, social, cultural e cívico, uma universidade de ensino pode ser também uma fonte de uma nova atividade econômica. A convergência do empreendedorismo, da hélice tríplice, do cluster e das estruturas da sociedade civil, exemplificado pelo caso de Ashland, pode fornecer um modelo tão instrutivo como o do Silicon Valley, àqueles que buscam uma teoria geral e pratica da inovação regional. A sociedade civil vibrante que oferece um solo fértil para o empreendedorismo cívico e a hélice tríplice aumentam as interações em cluster.

\section{Multilingual abstracts}

Please see Additional file 1 for translation of the abstract into Arabic.

\section{Introduction}

Local innovation systems may be generated and regenerated from acts of civic as well as business entrepreneurship from the launch pad of a vibrant Civil Society. Anthropologist Margaret Mead (1964) famously posited the axiom: "Never doubt that a small group of thoughtful, committed citizens can change the world. "'a Benjamin Franklin and his mates organized a public library and other civic ventures in mid $18^{\text {th }}$ century Philadelphia (Franklin, 1771). A San Francisco woman, using the municipal arts society as a platform, organized a successful movement to save the city's historic cable car railways that were part of the city's identity from being replaced by motorbuses in the early post-war. Three Berkeley women organized a movement that saved the San Francisco Bay estuary, the defining characteristic of the region, from encroaching development and environmental degradation in the 1960's. Similarly, a college instructor inspired the citizens of Ashland, Oregon, a small town in the American west, to organize a theater festival during the 1930's depression, whose development we examine in this article.

Such bursts of collective creativity were early noted as a distinctive feature of American society by European visitors (de Toqueville, 1851) and may be identified as civic entrepreneurship (Henton, Melville and Walesh, 1997). Civic entrepreneurship is the free contribution of time and effort to a project for the greater good of society without expectation of financial benefit. Self-expression, opportunity for creativity and to "give back" to the community is the motivation; reputation is the reward and social capital is the byproduct. Undertaken by a community to enhance its quality of life, such mobilizations of voluntary activity may increase economic capital and produce a new 
civic identity. It has been noted that some firms succeed in the face of limited resources making do with whatever resources are at hand (Baker and Nelson, 2005). A charismatic individual with a novel idea may go a step further and inspire moments of entrepreneurial bricolage, creating new resources to accomplish a project.

The transformation of a natural resource-based town into a cultural hub is examined through interviews with key informants, archival research and comparative case studies. This article is divided into five sections. First, we develop a typology of entrepreneurship, with a specific focus on civic entrepreneurship, the root concept of this paper. The next section discusses the necessary and sufficient conditions for creation of cultural clusters. Section 3 provides a case study of the Oregon Shakespeare Festival (OSF), including the symbiotic relationship between the Festival and the local university. Section 4 discusses the transformation of Ashland's economy. Finally, we return to the opening theme and discuss the role of Civil Society as the dynamo of civic entrepreneurship.

\section{Entrepreneurship and Knowledge}

Entrepreneurship is the vita activa of innovation, an expression of human need to organize and seek improvement (Arendt, 1958). Commercial, social and humanistic entrepreneurships are specified according to their objectives, just as capitalism has been deconstructed into distinct varieties (Hall and Soskice, 2001). The various entrepreneurships figured in different phases of Ashland's reconstruction: academic entrepreneurship begat civic entrepreneurship that begat cultural entrepreneurship that led to economic entrepreneurship.

These various forms of entrepreneurship transcend business risk taking (Cantillon, 1775). Schumpeter (1951) expanded the actors from individual to organizational and different types of entrepreneurship were identified e.g. Institutional (Dimaggio, 1988); University (Etzkowitz, 1983) and purpose Social (Dees, 1998. Taking entrepreneurship beyond the existing societal framework, institutional entrepreneurship creates alternative rules and logics (Garud and Karnøe, 2001; Leca, Battilana and Boxenbaum, 2008) in contrast to moral entrepreneurs who act to reinforce existing norms e.g. Prohibition (Becker, 1963).

\section{Entrepreneurship classification}

- by target/mission (why)

commercial entrepreneurship

social entrepreneurship

humanistic entrepreneurship

- by actors (who)

Collective entrepreneurship

(such as institutional, community, civic entrepreneurship)

Individual entrepreneurship

- by content fields (what) -- political entrepreneurship , cultural, scientific, technology, educational, academic, arts entrepreneurship.

We classify entrepreneurship as three basic forms by main missions and targets of the entrepreneurs, i.e., humanistic entrepreneurship (HE), social entrepreneurship (SE) and commercial entrepreneurship (CE). Each type of entrepreneurship is classically 
associated with a particular type of venture: commercial entrepreneurship with a business firm, whether spun off from an existing business, academic research or is the realization of an individual or group's idea; social entrepreneurship with a business venture that is also targeted at improving the welfare of an underprivileged community (Paredo and McClean, 2006); humanistic entrepreneurship refers to a project for enhancement of the quality of human life, as an individual or community member, through religious, spiritual or artistic knowledge. And civic entrepreneurship is in the overlapping space of both HE and SE, since civic entrepreneurship is both for oneself and other social groups, and both for social impact/ value and also for individual and community improvement (Figure 1).

Knowledge-based entrepreneurship has potential beyond high-tech. Technological Innovation Systems (TIS) referring to a knowledge field like signal processing or a specific product e.g. biofuels (Bergek et al. 2008) may be extended to the humanities. Thus, Renaissance studies (knowledge field) or Shakespeare plays (product) may be viewed as a globally distributed TIS instantiated in various venues (Ashland, Stratford, Connecticut and Ontario, Santa Cruz), with nodes (OSF) and links, (Stanford) and flows from one to the other, e.g. the OSF trained Shakespearean actors who filled lesser roles in the star oriented Connecticut festival (Figure 2).

To accommodate the humanities and social sciences, TIS might be relabeled Knowledge Innovation Systems (KIS). The various processes of knowledge diffusion, if not development, entrepreneurial experimentation, market formation, legitimation, resource mobilization and positive externalities in the TIS checklist may be identified in the Ashland case. Key hypotheses:

1. A teaching university's knowledge base is a relevant resource for economic and social development.

2. A spin-off may be created from virtually any form of knowledge: literary as well as scientific, social science and engineering.

3. A university may be a significant factor in cluster growth and vice versa as cluster development contributes to academic advance.

\section{Clustering for Innovation and Growth}

The cooperative dimension of economic activity has been rediscovered. (Boschma, 2005). Formats include: simple clusters consisting of similar contiguous firms, each producing virtually the same product, e.g. the gypsum cluster in Recife, Brazil or the Scotch whisky producers that find benefits in sharing certain information, flying a common banner and engaging in joint lobbying and representation activities; integral clusters consisting of a symbiosis among member firms, each contributing a special element to production and distribution as in the Third Italy leather and clothing industries (Schmiedeberg, 2010); knowledge-infused clusters, with ties to universities and research institutes that enhance human competence levels and introduce an innovation dynamic based on research as well as classic tacit knowledge accretion, the forte of traditional clusters.

A progression may be identified from simple to integral to knowledge-infused clusters. Nevertheless, cluster development phases are non-linear and may occur in various orders, with reversal, expansion or contraction (Etzkowitz and Klofsten 2005): (1) Inception: 
Founding of the root entity (2) Institutionalization: sufficient resources are generated to insure survival; (3) Efflorescence: additional entities are founded, similar to the original one producing a simple cluster on a basic theme i.e. a theatre cluster (4) Differentiation: founding of organizations on related themes e.g. Edinburgh fringe alongside an international arts festival, art galleries, with restaurants and hotel businesses living off and supporting the original Ashland cluster; (5) Finally, a Knowledge Infusion phase may be identified in which existing or new universities introduce novel elements e.g. new kinds of liqueurs in the Cognac region of France (Sack, 2014) and a Shakespeare festival in Ashland, Oregon.

Ashland theatre companies constitute a simple cluster, in their interrelationships, in contrast to most area firms that function as isolated entities, located in the region due to owners' lifestyle preference despite higher costs of doing business. Introduction of additional arts and ancillary tourist businesses has created a more complex format with some of the characteristics of an integral cluster. Ashland's clustering phenomenon was knowledge-infused from its outset, originating from knowledge embodied in academic professionals and the humanities literary cannon.

Regional innovation is reformulated from a single (business) to a dual (state/industry) focus to a triple helix configuration (Etzkowitz, 2008; Qian, Acs and Stough, 2012). Among the factors that encourage cluster growth are availability of government procurement funds to drive a learning curve (Lecuyer, 2007) and insertion in a supportive eco-system with venture capital, legal assistance and firms in related business fields (Lee et al. 2000). Relative absence of these factors formerly led computer firms located at the Rensselaer Science Park in Troy, New York to move to Boston. Lack of leadership inhibited knowledge-based growth for a time in New Haven and Oxbridge. On the other hand, one of the factors held to inhibit growth e.g. "greenbelt areas" has been found to be irrelevant as firms jump over the Cambridge Greenbelt and locate in neighboring towns (Lawton-Smith, Romeo, and Waters, 2013).

A cluster policy "...entailing active management of information and of knowledge at the cluster level" typically emerges in response to competitive challenges (Amisse, Leroux, and Muller, 2012). It can include a strategizing capability like the Electrum Foundation in Stockholm's KISTA Science Park that inserted an IT University to spawn spin-offs when the Park lost its anchor tenant. Stanford's Center for Integrated Systems was a university-industry-government initiative responding to the rise of the Japanese semiconductor industry. In an environment with legal restrictions and lack of an entrepreneurial culture, incubator projects and entrepreneurship training programs addressed Brazil's innovation deficits (Etzkowitz, Mello and Almeida, 2005). Yale's biotechnology firm formation strategy, used the school's reputational and social capital to attract financial capital from the nearby Stamford venture capital community (Breznitz, 2007).

\section{Transmutation of Capitals}

Capitals are exchanged in a virtual bourse: civic into reputational, reputational into social, financial into cultural, cultural into financial (Bordieu, 1986). "Dual-life persons," like Ashland's Bowmer, with a foot in different camps, often perform the exchange function. In another instance, a late 19th century Bostonian financial entrepreneur with an artistic bent, Henry Lee Higginson, applied models of formal organization, drawn from business, to distinguish high arts from low arts, shaping independent musicians 
into a disciplined organization, the Boston Symphony. Transmuting financial into cultural capital, Higgenson and his colleagues built museums and concert halls, taking control of the arts from artists and their informal organizations (Dimaggio, 1982).

The evolution of the Edinburgh fringe festival illustrates the dialectic between cultural and business entrepreneurship (Lee, 2012). Begun spontaneously by theater troupes that showed up to take advantage of the audience potential generated by an official festival, the phenomenon was labeled by a journalist who defined its identity, much like the naming of Silicon Valley, after the semi-conductor cluster appeared. The Fringe festival engendered an informal support organization that was eventually formalized under pressure of fringe festival growth but elected representatives still represent performers. The fringe has become a networking and booking venue for individuals and groups, across a wide range of popular and performing arts. Demonstrating the attractive power of an anchor cluster, it is a tourist attraction in its own right alongside the official International Arts Festival.

A cultural cluster may arise from a stream of cultural activity that can be enhanced by policy initiatives and vice versa. The association between marginality and cultural entrepreneurship may be weak. The Ashland case suggests that relatively conventional persons may be cultural entrepreneurs as well as those on the outskirts of society. Thus, there is hope for "bourgeois" Kristiansand despite the concern expressed that the town does not meet "creative class" criteria (Florida, 2002; Kotkin, 2013). Stock sold in a municipal water power plant raised 170 million dollars for the Cultiva Foundation to promote culture, ranging from cutting edge artistic activity to more conventional leisure pursuits in Kristiansand, Norway (Lysgaard, and Tveiten, 2005).

Cultural clustering has become an explicit element of economic development policy (Lysgaard, (2011). As early as the 1977 New York Mayoralty campaign economic data provided by Lincoln Center for the Arts, showing the extensive contribution of the arts to the city's economy became the basis for a plank in a candidate's election platform. Municipalities and property developers now routinely invite artists to utilize empty storefronts on high streets and warehouses in declining industrial districts as working and living spaces at little or no cost, transforming a squatting technique into a gentrification strategy.

\section{Theatre Festival Bricolage}

In Ashland, civic entrepreneurship was institutionalized through triple helix interactions among a university (teaching college) Industry (theatre festival) and government at various levels (municipal, state and national). A platform of not for profit activity

Table 1 Classification of entrepreneurship ${ }^{b}$

\begin{tabular}{|c|c|c|c|}
\hline & Purposes & Missions & Who serving for \\
\hline$\overline{\mathrm{HE}}$ & $\begin{array}{l}\text { To enhance the quality of } \\
\text { life in a given environment }\end{array}$ & $\begin{array}{l}\text { Human improvement } \\
\text { in physical, mental and } \\
\text { spiritual aspects }\end{array}$ & An individual or community \\
\hline SE & $\begin{array}{l}\text { To create social value } \\
\text { and Social impact }\end{array}$ & $\begin{array}{l}\text { Seeking social impact } \\
\text { and creating social value }\end{array}$ & $\begin{array}{l}\text { Specific social groups such as the disabled, } \\
\text { the poor, women or children in poverty }\end{array}$ \\
\hline \multirow[t]{3}{*}{ CE } & \multirow{3}{*}{$\begin{array}{l}\text { To achieve economic/ } \\
\text { commercial profit/income } \\
\text { maximization }\end{array}$} & The best business & \multirow[t]{3}{*}{ Users of products or service } \\
\hline & & The most profit & \\
\hline & & Staff welfare & \\
\hline
\end{tabular}

Mapping civic entrepreneurship 
spun-off from the University's teaching mission generated profit-making ventures. Frustration at the meager resources available to pursue his vocation during the depression-era motivated Angus Bowmer, a drama instructor at the local university, to propose putting on plays as part of a civic celebration. His determination to overcome the obstacle of a paucity of academic resources in his specialty inspired the Oregon Shakespeare Festival (OSF) that developed into a cultural cluster.

Why Ashland rather than another Oregon town? A tradition of public spirit explains some of the town's mobilizing capacity for civic entrepreneurship. The town's founders had donated land for common facilities such as Lithia Park, the eventual home of OSF. The festival built upon the town's cultural substrate as regional headquarters of the Chautauqua movement, whose summer gatherings across the United States featured lectures, entertainment and occasional religious revivals in the late $19^{\text {th }}$ and early $20^{\text {th }}$ centuries (Gould, 1961). It has been noted that, "Oregonians tend to be joiners with some of the higher rates of volunteerism in the nation. Words like "community" and "social justice" get repeated in public life like mantras" (Johnson, 2013).

As a Normal School, SOU was oriented towards the humanities, with a component of performing arts, reflecting the curriculum of the schools that it provided with trained personnel. Moreover, teachers college performing arts curricula are strongly oriented to practice since a good part of the remit of a high school drama teacher is coaching their students to mount a performance. Theatre is a collaborative art. The theatrical ethos implicit in, "Let's put on a play" was congruent with taking this mission beyond the boundaries of the college. When the practical arts mission of a teachers college was scaled up to the community level, it was a leap that was within reach. Based on the theatre arts and humanities, rather than engineering and the sciences, and on teaching rather than research: community theatre was in tune with the college's mission.

There was no grand vision of collaboration between theatre festival and university at its inception. The site of the first Shakespeare festival housed performances during the Chautauqua era. The first Chautauqua building, built in 1893, was enlarged and then replaced by a dome-covered structure in 1917 that was torn down in 1933 after the Chautauqua movement died out in the early 1920's. The movement's decline left behind the physical base of a demolished auditorium that was re-imagined to fit the form of an Elizabethan theatre. Indeed, Bowmer thought the Chautauqua walls resembled pictures he had seen of Elizabethan theatres and recycled them as the frame for the initial outdoor theater.

The Oregon festival was not a unique phenomenon at the time as cultural ventures were begun in other depressed regions, providing a platform for their initiators while demonstrating the utility of the arts. For example, "In a typical situation found during the Depression, a couple of enthusiastic people-in this case the fledgling artist, Lawrence Hinckley (1900-1987) and his wife Mildred, put forth a tiny bit of money and a lot of effort and turned a family barn into an art gallery that eventually became the pride of the community" (Moure, 1998: 236).

\section{Civic Entrepreneurship in Depression Era Ashland}

In his autobiography, Bowmer said that, "In coming to Ashland I faced the most bitter disappointment I had experienced in my young life. Southern Oregon Normal School ${ }^{\mathrm{c}}$ did not have a drama department" (Bowmer, 1975: 39). "[Bowmer] realized that, if [he] 
were going to develop an extensive extracurricular theatre program, [his] first task was to gain the support of faculty, student body, and townspeople for the project" (Ibid. 40). He convinced the Active Club, a community service group of businessmen and professionals in which he was a member, to propose including "The First Annual Shakespeare Festival" in the revival of Ashland's Fourth of July "Independence Day" celebration. Started in 1935, the initial two Festival plays were cast from the School's faculty, students and townspeople.

The festival incubated within the College as an informal entity. The Normal School presented the second Festival, making a profit of $\$ 84.23$. Although President Walter Redford promised Bowmer that the funds would be "earmarked" for OSF, the college spent the money on another public entertainment, outfitting its football team instead. The impetus to spin-off came from this raid on the Festival's earnings. Bowmer and his associates organized the Oregon Shakespearean Festival Association, a non-profit, educational institution so that OSF could control its finances and destiny.

With sources of support in the business and professional community, as well as local government, OSF could survive the vicissitudes of temporary loss of support from any single partner. Due to Bowmer's role in both the College and the community organization, OSF had a stronger take-off velocity that if it had had to rely on a single source of support, like the ill-fated 1935-36 Stanford Shakespeare festival that was not revived once it lost its academic sponsorship. When the Ashland Festival reopened in 1947, after a wartime hiatus, “...members of the community, especially the college community, became enthusiastic participants in readying the theatre for occupancy" (Ibid 162). Thus, the social capital generated from civic entrepreneurship helped restart the Festival, even after a time lapse.

\section{Overcoming Social and Intellectual Capital Deficits}

A Department Chair rejected a similar attempt to spin-off a community theatre at Stanford University, during the same era. Prof. Margery Bailey's summer Shakespeare festival on the Stanford campus was shut down after two seasons when it was decided that public performances were not in accord with the university's education mission. ${ }^{d}$ John Maynard Keynes justified his plan to build a theatre at Cambridge University in 1934 on the grounds that a, "theatre [is] as necessary to the understanding of the dramatic arts...as a laboratory is to experimental science". Of course, a university theater is more than a laboratory to understand drama; it is also a medium of dissemination to "publish" the result. Unfortunately, the Kings College Council rejected their bursar's proposal to extend the purview of this elite institution from the arts and sciences to the performing arts (Sidelsky, 2003: 523).

Stanford supported Frederick Terman's engineering entrepreneurship in the same era that Margery Bailey's humanities entrepreneurship was rejected. Bailey regrouped at Stanford, organizing a new plays competition that she ran for decades, with participation of leading American theatrical figures as judges. Gender roles, doubtless, were a factor but the culture of the two schools, no doubt, also played a role, with the Oregon teacher training college, heavily oriented to the humanities even as Stanford was engineering focused. Even as technical enterprises were being hatched on the same campus, a more constricted academic culture in the humanities inhibited a parallel arts entrepreneurial initiative ${ }^{\mathrm{e}}$. 
Despite Palo Alto being in closer proximity to a greater audience watershed, relatively remote Ashland became the arts and humanities cluster while Palo Alto had to settle for Silicon Valley! Prof. Margery Bailey, a member of Stanford University's English Department, with a specialization in Elizabethan literature and an interest in promoting campus performance of Shakespeare, who had entrepreneured the Stanford Festival, wrote Bowmer that he had accomplished, "... what....... and the rest [west coast theatre academics] have been trying to do for years," Bailey connected with the Ashland festival in the early post war, adapting the Stanford geology department's field study format to offering courses on Elizabethan theatre at the festival.

Bowmer came to Stanford to work for a PhD with Bailey, solidifying an academic link between the two schools that continues to the present, with Stanford academics offering public lectures at the Festival. SOU President Elmo Stevenson soon invited Bailey to teach her courses in the SOU summer school, integrating, "...our summer schoolwork in drama, art and literature into the festival ${ }^{g}$. Bailey founded the SOU Institute of Renaissance Studies, bringing academic analysis of Elizabethan theatre together with performance. Combining theory with practice, as an actor and as author of a critical analysis of the season, she eventually donated her collection of folios to the Institute (Shakespeare Newsletter, 1956).

Both festivals were initiated by academics, the Stanford by a female English Department Professor with a Yale $\mathrm{PhD}$ and the Ashland by a male drama teacher with modest academic accomplishments. Bowmer was integrated into a local network of business and professional persons while Bailey lacked a strong local network. Bailey's peers were fellow English Department academics with a theatrical bent at west coast and inter-mountain west universities, who provided each other with a collegial support structure through correspondence and visits. The 1930's SOU/Stanford theatre experiences suggest the importance of access to resources in the community, especially when internal resources are few. The Santa Cruz Shakespeare Festival, a deficit making project of the University of California, Santa Cruz that recently closed its doors has reopened as a spin-off in its traditional campus venue after a successful local fund raising campaign (Bain, 2014). In general, civic support is the most significant factor in Shakespeare Festival success.

Other venues also have Shakespeare Festivals, with a variety of fates. The Stratford Ontario Shakespeare Festival was the brainchild of a local journalist, concerned about the loss of the city's railway industry. He convinced the town council to provide modest support to explore the idea with a grant of 125 dollars to seek artistic advice. Piquing the interest of a British theatrical luminary, the project thus legitimated, received local business and government support to begin the festival in the mid 1950's. The original theatre, focused on Shakespeare, developed into a broader theatrical complex of three houses, with a more extensive repertoire, and eventually generated a specialized academic unit, the Birmingham Conservatory for Classical Theatre, to train actors.

The existence of the theater festival encouraged creation of other arts venues in music and visual arts in Stratford. Taking advantage of Victorian architecture, as the location for boutique accommodations and restaurants to support the arts attractions that draw visitors from Toronto and the US. Stratford has become Canada's premier arts town. Stratford Ontario has developed into a self-sustaining cluster, with an academic offshoot. Although its specialized acting school is an outcome of the theatre festival rather than source of it as in Ashland, it is noteworthy that the trajectory of a 
successful theatre festival generated an academic institution, specialized in the theatre that will solidify its base. Shakespeare himself asked, what is in a name? The answer is that it can be an inspiration to civic entrepreneurship.

The experience of another Shakespeare Festival reinforces the importance of local support. The Stratford Connecticut Festival, founded by New York theatre luminary, Lawrence Langner, together with such well known theatre personages as Lincoln Kirstein, founder of the New York City Center Theatre, Theresa Helburn, co-producer of the Theatre Guild, a non-commercial alternative to Broadway, Roger Stevens, noted producer and Maurice Evans, distinguished actor. Although Langner was a founder of the Theatre Guild, Stratford followed the Broadway model in emphasizing stars, expensive productions, and a theatre building, rather than the simple structures that characterized the beginnings of regional festivals, like Ashland. The Ford and Rockefeller foundations supported the theater and no less a personage than Winston Churchill sent a congratulatory message for the Festival opening.

Nevertheless, the path was not smooth. The residents of Westport Connecticut, an upscale community opposed the Festival, causing it to be relocated to Stratford, an industrial town. The project moved top-down, with support of the state's governor, a Broadway theatrical elite and supporters from," ...the worlds of finance, law, retail and government and publishing" (Cooper, 1986: 19). The Connecticut festival attempted to generate a training program but its support base was too small to carry both a performing and an educational project whereas OSF could always rely on SOU with its independent support base. Without significant local roots, external support waned and the American Shakespeare Festival closed in the mid 1980's. The town of Stratford, supported by local volunteers, has since attempted to make the shuttered theater a tourist attraction.

The New York Shakespeare festival, begun in the same era by Joseph Papp, a visionary theatrical entrepreneur, touring New York City with Shakespeare productions performed on a flatbed truck, showed steady growth and greater staying power. It scaled up gradually, as support grew, to a summer theater in Central Park and a theatre complex downtown in the renovated headquarters of the Hebrew Immigrant Aid Society. The New York Shakespeare Festival, now the Public Theatre, developed a symbiotic relationship with Broadway, moving its successful productions to the commercial stage and recycling funds to support its non-profit theatre.

After a period of initial ambivalence, city government also became a strong supporter, including construction of a theatre in Central Park, in recognition of the Festival's contribution to civic life and tourism. Indeed, it was the very same Robert Moses who almost destroyed the emerging SoHo arts district (Jacobs, 1961) who was the initial opponent but, when turned around, is reported to have said, "Let's build the bastard a theatre". New York provided Papp a broader venue for his efforts than Ashland offered Bowmer. However, they are similar in the civic support they engendered and the clusters they generated, as an enclave within the broader theatrical scene in New York and de novo in Ashland.

\section{University (Theatre) Industry Links}

Southern Oregon University and the Ashland cultural cluster grew hand in hand, with the cluster spurring the academic development of its parent. A new SOU theatre facility, built in 1982, made SOU more attractive to OSF staff especially willing to help with the Master of Theatre Studies in Production and Design. A former teachers college is 
now Southern Oregon University (SOU) with a competitive theatre department. The upgrading is a typical academic progression. For example, Albany State Teachers College became the University at Albany, upgrading from teachers education to providing social science expertise in fields like criminal justice to state government and then a nano-science and technology research center in collaboration with IBM to build a semi-conductor industry.

Bowmer's and Bailey's dual roles in OSF and SOU helped build a variety of links. Offer of teaching positions at SOU assisted recruitment of company members, especially before OSF built its reputation. The SOU Center for Shakespeare Studies, founded in 1986, combines Shakespeare analysis and production in a Shakespeare Studies minor with OSF actors and directors as guest faculty. Its relationship with OSF helped the Center pioneer the national teaching from performance movement. From 1987-2005, summer institutes, sponsored by the National Endowment for the Humanities, helped teachers teach Shakespeare. OSF and SOU also organized the Spring Shakespeare Symposia for California and Oregon high school teachers to prepare their classes for OSF performances.

As the festival gained prominence, SOU's relationship with OSF helped improve its theatre department. Theater professionals 'right down the street', serving as adjunct professors provided, "unimaginable access" as a student noted. Student interns were treated like company members at OSF, gaining experience that helped in admittance to Master of Fine Arts programs. The Shakespearean Festival and Summer School, begun in the 1949 Festival season, offered ten courses that had a regional reach to west coast students, south to Stanford University and north to Washington State University ${ }^{\mathrm{h}}$.

Many students matriculate at SOU, inspired by a school visit to OSF that included a campus stay, encouraging them to identify as college students. An SOU admissions officer, visiting high schools in California, reported that, "a girl told me 'I am an SOU student!' and whipped open her wallet, proudly showing me her SOU cafeteria meal card from her visit to Ashland." Although planning to attend Northwestern, a nationally known theater arts school, a high school student stopped by the SOU campus on a trip to OSF. She spoke with an acting professor about the school's relationship with OSF and ended-up attending SOU. Another student who began attending OSF as a 15 year old decided to attend SOU because of its relationship with OSF.

As SOU has grown so has OSF, which increases the potential for SOU graduates and alumni to find employment and internships. Just as other theatre groups, such as ANPF, want to collaborate with SOU, businesses in the area want to partner with SOU. The business community in Jackson (where Ashland is located) and Josephine counties would like SOU's School of Business, “... to become more engaged with the local economy," to do research relevant to the area, hold conferences on business issues, and for SOU to become a center for entrepreneurship and offer greater support to startups and small businesses (Reid, Schein, and Wilson, 2006: iv).

The inter-related roles of the three levels of US government in fostering innovation and entrepreneurship have been called a "triple helix within a triple helix" (Penska, 2013). In the Ashland case, municipal government provided town land for the theaters at nominal cost and supported the construction of parking facilities. The city helped OSF obtain a low-interest loan to build its New Theatre through the state of Oregon as well as covering a portion of the loan payments for its garage. OSF also receives a 
portion of the Transient Occupancy Tax (TOT) on overnight accommodations. The original theatre was built with Works Progress Administration (WPA) funds in the 1930's and, in the 1960's; a matching grant from the US Economic Development Administration, facilitated by state government, completed the fund raising for the theater expansion project. While a fundraising campaign raised $\$ 1,000,000$, this was insufficient so the matching grant was crucial. The money went to Ashland as the project was built on city land that OSF then leased (Bowmer, 1975, 262-3).

\section{Making a humanities town}

Ashland may be viewed as a local innovation system (LIS) a smaller scale unit than a regional innovation system (RIS). Many US towns of the scale of Ashland (current population 20,000) and Truckee, California have their own economic development units with planning and implementation expertise. Indeed, an LIS is typically enacted within a municipality whereas the regional level in the US is more likely to be more a cultural than a political entity, with special purpose districts such as the San Francisco Bay Coastal Management Program and membership organizations like Joint Venture Silicon Valley.

Ashland is in the Rogue Valley, a rural region near the Oregon-California border. Its economy was based on resource extraction and its location as a railhead, until superseded by a grade improvement in 1929. The creation of a market for theatrical performance was facilitated by the town's serendipitous location near Portland, Oregon and the San Francisco Bay Area. Ashland is widely known on the west coast and inter-mountain west and attracts visitors from Portland, the Bay area and beyond. The town's image is projected internationally as a distinctive tourist destination, like Santa Fe, New Mexico, with its summer opera festival, Boulder, Colorado with its Buddhist cultural scene and Laguna Beach and Carmel-by-the-Sea, California, with their arts colony origins.

A theatre cluster with various theatre companies and festivals developed from OSF's success. In 2011, attendance was 390,347, in comparison to 80,000 per summer for the NY Shakespeare Festival. The Ashland New Plays Festival (ANPF) devoted to new plays, enhances Ashland's theatre reputation, drawing additional visitors and encouraging longer stays. According to its President, a portion of ANPF's success can be attributed to the success of OSF as "...good theatre...makes people want more of it." There is cross-fertilization of talent at both festivals, for example, the ANPF Artistic Director, is also an OSF actor and key node of a network among the companies.

A new cultural economy was generated that also attracted government support. The penumbra of other theatre companies and cultural activities that grew around OSF changed the image of Ashland to an arts and humanities town. The diversification from theater arts to visual arts, renewal of the pre-festival hot springs attraction and development of ancillary shopping, art gallery and tourist facilities supports thriving upscale bed and breakfast and restaurant industries. A locovore restaurant scene has proliferated, drawing upon the region's agricultural assets (Margulis, 2014). Coffee houses and bookshops fill the interstices of visitors' time also making the town more attractive to residents.

\section{Recycling Urban Infrastructure}

An historic venue, especially a relatively ordinary one, provides a non threatening scene to relax and wind down to the slower pace associated with modest Victorian style 


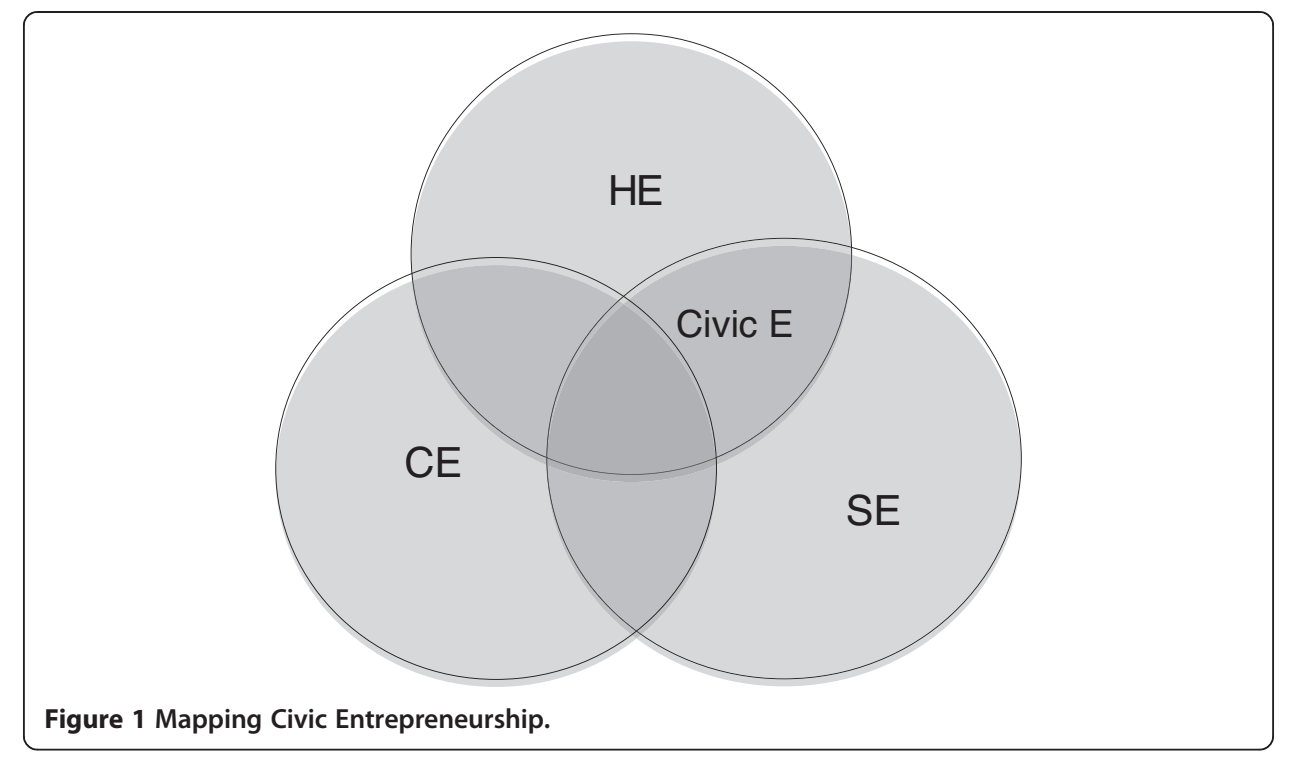

houses and a Main Street with local shops, characteristic of an earlier era. Thus, the tight urban environment, required to call together rail crews quickly, provided a useful resource to recycle and expand upon decades later. Ashland's economic development leadership protected and enhanced its classic business district and resisted the infusion of suburban ambiance that characterizes its closest neighbor.

The upper working class houses of railway brakemen and engineers and a transient rooming house with a fading coca cola mural on its side, have been renovated into elegant bed and breakfasts, restaurants and coffee houses without a Starbucks marquee. The town's classic hotel, originally built as a destination for the therapeutic waters of Lithia Springs, has been cautiously renovated to retain its early $20^{\text {th }}$ century ambiance. The current management is committed to, “...resurrecting those, 'Taking to the Waters, simpler times” when Ashland was known as America's Baden-Baden'. As suburbanization engendered nostalgia for small town America, tourists wish to temporarily enter an alternative social reality in their everyday life as well as in the theatre.

\section{Town Renewal}

OSF has grown into a national cultural phenomenon, acknowledged by the New York Times as early as 1948 (Neuberger, 1948) and into an engine of economic regeneration. SOU and OSF, as the two largest employers, combined with a strong tourism industry, are the foundation of Ashland's economy. OSF employs approximately 575 theatre professionals and attracts nearly 600 volunteers. The growth of OSF is also seen beyond employment numbers. Approximately half of Ashland's visitors attend plays, with visitors significantly increasing the patronage for local stores and boutiques. In the past 20 years, Ashland's economy, in addition to manufacturing and specialty foods and beverages, has relied on SOU, OSF, as well as lodging, restaurants, and specialty retail, much of it spun-off or attracted by the Festival (Figure 3).

OSF attracted actors who came to perform; some moved to the town and made it their base or came for retirement. OSF also draws retirees from among theatre 


\section{QuickTime $^{\mathrm{TM}}$ and a decompressor are needed to see this picture.}

Figure 2 Development Conditions of Five Shakespeare Festivals.

attendees for whom it is an attraction along with Ashland's affordable standard of living, especially for immigrants from the Bay Area. Ashland was ranked $16^{\text {th }}$ in the 2010 CNN Money Guide to the "25 Best Places to Retire" in the US. In an earlier era Ashland economy's was based on mills and its demographics on families and children. Ashland's shrinking working class opposed the focus on the arts and on the downtown supported by the university and the business community. While cultural activities have benefitted the economy, some feel local government pays too much attention to the arts. Avoiding the "ghost town" fate of many western towns that have lost their extraction economies, Ashland renewed itself through rise of a new middle class of "cultural workers" as theatre became the economic base of the town.

\section{The Institutionalization of Founder's Charisma}

OSF combined public entertainment with dissemination of scholarship on the Elizabethan era. Similar venues, associated with the visual arts and music, like the Marlboro Music Festival at Marlboro College in Vermont, can be identified across the country. Few have had such a sustained growth and expansionary dynamic as Ashland's festival that became the core of a new civic identity. Not surprisingly, there is "a cult of Angus Bowmer" who is revered by many of the Festival's older supporters. Indeed, Bowmer's persona has eclipsed the contributions of Ashland townspeople and Stanford academics that supported the founding and growth of the festival, much as the Steve Jobs aura has overshadowed Apple's other founders (Isaacson, 2011).

Ashland's prime attraction, live theatre, is a consistent and continuing stream of activity based on a common model, like the proliferation of $342^{\text {nd }}$ hand bookstores in the Welsh town of Hay-on-Wey that engendered a literary festival. Sponsored by a national newspaper, it draws 80,000 visitors. Bibliophile Richard Smith, the originator of the town theme, was credited with having changed Hay, "... from a small market town into a mecca for second-hand book lovers and this transformed the local

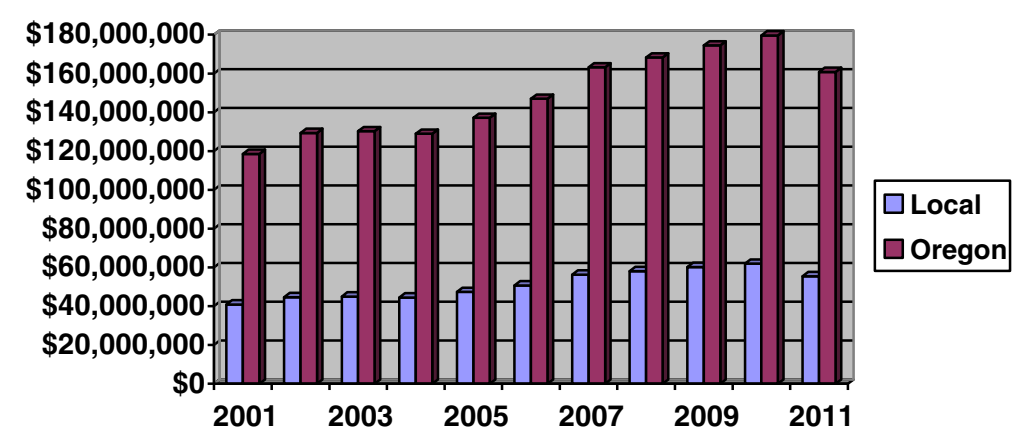

Figure 3 Economic Impact of OSF ${ }^{k}$. 
economy" (BBC, 2005). The "book town" model has spread to other European countries. By, "...pioneering the presence of theatre in Ashland, OSF has paved the way for other theatre companies [in town] to succeed as well." (Ashland, Oregon Chamber of Commerce, 2012:25). OSF itself has grown to an eight month long season of eleven plays, going beyond Shakespeare to contemporary as well as classical repertoire, as only four of the eleven plays this past season are Shakespearean. Indeed, the Ashland experience inspired the southern Utah Shakespeare Festival mounted by a local university.

The Ashland Festival attracted attention well outside the region, initially within its catchment area and then nationally. OSF was invited to perform at the 1939 World's Fair in San Francisco and the performance was broadcast nation-wide, enhancing the projects legitimacy. In the early post-war, shortened versions of OSF performances were a regular feature on the National Broadcasting System, a network that also promoted high culture by supporting the NBC Symphony Orchestra that Arturo Toscanini conducted. Whereas, the NBC Symphony, a corporate attribute, was disbanded after Toscanini's death, OSF institutionalized Bowmer's charisma (Weber [Eisenstadt], 1968), producing a social world, “...which exists historically prior to the actors..." and furnishes an objective structure that they reenact (Zucker, 1977).

Cultural clusters generate gentrification dynamics by producing residential amenities as a side effect of their growth. Artists manual skills proved useful in renovating discarded venues, setting in motion a gentrification dynamic (Etzkowitz and Raiken, 1980). Cultural entrepreneurship morphed into business entrepreneurship as production of art also engendered galleries for the sale of art and ancillary cafes, coffee houses and restaurants to service the visitors. Streams of visitors made the area attractive for retail ventures and the cultural ambiance attracted non-artists who appreciated their life style and made it their own.

Policy initiative has more recently become the first step, with funding mechanisms targeted at the origins as well as the growth stages of cultural entrepreneurship. Contemporary cultural entrepreneurship is exemplified by such high-profile international collaborations carried out at great expense by joint public/private donors, like the Guggenheim Museum in Bilbao that has transformed the image of this declining industrial city and made it a cultural icon and tourist destination (Hall, 2004). An economic success, the Museum has drawn visitors that utilize the towns existing hospitality structure on weekends and summer months when business visitors are less present (Plaza, 2008). Its long-term success may be judged by whether the project also generates a local artists quarter, galleries and spillover cultural events.

\section{Bottom Up Vs. Top Down Strategies}

Like their Soho New York counterparts, artists had begun to settle in abandoned factories along the diagonal roadway in the wake of the 1992 Barcelona summer Olympics that stimulated a variety of economic regeneration projects. ${ }^{1}$ One such plan, supported by the municipality, was to turn the district into a center for high tech development, replacing most of the old factories with new construction and providing high band width and other technological infrastructure to attract technology firms and branches of universities. An early step was to call in the police to remove the artists who were viewed as an obstacle to 
the high tech image fostered by the Arroba 22 project. Years later, recognizing their mistake, Arroba 22 invited the artists to return but the damage had been done in cutting off bottom-up artistic entrepreneurship ${ }^{\mathrm{m}}$.

A similar fate might have befallen New York's Soho. Robert Moses, the master rebuilder of New York from the depression era into the 1960's, had amassed the capability to push through large projects by simultaneously leading several state, city and crosscutting administrative agencies, like the New York Port Authority. He had developed a plan to build a major highway through SoHo and neighboring Greenwich Village that was successfully opposed by Jane Jacobs, a civic activist and urban theorist, who led a small citizens group. (Caro, 1974). Exemplifying Margaret Mead's thesis of the power of a committed citizenry, SoHo was saved for artists, allowing space for a bottom-up model of arts-based urban regeneration to emerge (Jacobs, 1961).

Cultural clusters often overlap various arts and their existence may be obscured by narrow SIC codes that may not indicate sufficient activity in a single code to count as a cluster (Porter, 1998; Reid and Schein, 2007). Typically a particular art, whether performing of visual, is the initial source of the cluster that, over time, attracts additional arts and generates ancillary economic activity related to tourism. A niche activity in metropolises, tied to the renovation and gentrification of former industrial and commercial districts; the processes of cultural cluster formation and growth may be the mainstay of a local economy in small cities. Ashland and other cultural cluster success cases combine bottom-up initiative with top-down support and lateral links across the institutional spheres, rather than relying on a narrow base.

The Edinburgh fringe, Ashland and New York's SoHo were bottom up developments. Although eventually superseded by gentrification pressures, SoHo was assisted by measures, such as a "licensing" procedure, authorized by the municipality and implemented by an artists organization, to restrict residency to working artists (Etzkowitz and Raiken, 1980). The Edinburgh Fringe apparently remained self-organized even as it spun off year-round theaters in the city (Lee, 2012). There is a lesson here for state supported cultural organizations in Europe, like the regional Italian opera houses. While they retain considerable popular support, reliance on national government funding, that is sharply reducing, threatens their viability. Just as European universities have organized alumni associations in recent years to increase their support base, state supported cultural organizations might look to their local supporters and organize them in associations with governance authority, thereby increasing their ability to generate local support.

The 2008 downturn reinforces the importance of a cluster with deep roots and potential for continuous reinvention. Rustbelt cities that attempted to instantly reinvent themselves by importing attractions from afar might also explore the potential of local educational and knowledge resources and previous industrial traditions. Under pressure of rising unemployment in 2010, the state of Rhode Island committed 75 million dollars to an enterprise promising immediate job creation in complex computer games, a field where there was no previous local experience. A large number of jobs were temporarily created in an isolated venture but the firm soon closed and Providence has reverted to a longer-term strategy relying on its strong local knowledge base in medicine and design (Bai, 2013). 


\section{Conclusion: Civil Society: Helix or Platform?}

Civil society consists of free associations of people that cross cut conventional institutional spheres, facilitating initiatives in which capitals are transmuted one into another. The ability to meet together, speak freely, and form new organizations, encourages social experimentation. Civic entrepreneurship thrives on this base, allowing entrepreneurial bricoleurs the freedom to innovate. Civil society is too fundamental a phenomenon to be a parallel institutional sphere, with single or dominant and subsidiary institutional logics (Carayannis and Campbell 2009). Rather, Civil Society is the launch pad for take-off of triple helix interactions. The antithesis of fluid Civil Society is a totalitarian regime that limits if not forbids free association. Nevertheless, a sliver of Civil Society may emerge in authoritarian societies bottom-up via samizdat and in strictly delimited "pockets" of free association for highly specific innovation projects that are useful to the regime (Solzhenitsyn, 1997)

A vibrant civil society provides a platform for optimal triple helix interactions that foster 'innovation in innovation', new organizational inventions that promote innovation. Entrepreneurs will find ways to work around restrictions but entrepreneurship, in its various forms, thrives most fully when it is encouraged. Whereas a town may thrive on a single cluster, a region requires a series of interrelated self-renewing clusters to be a Technopole that is viable across the generations (Boschma and Fernahl, 2011). Knowledge that is reinterpreted for a new generation, the special competency of the humanities, may be as significant for economic development, as knowledge generated by experimentation, the forte of the sciences.

Ashland focused on Elizabethan theatre, a field in which it had a modest competence. Attracting a Stanford scholar and numerous actors who had performance experience enhanced its competence base. Ashland's sister city might be Norrköping, a Swedish town, formerly based on paper mills, that is reinterpreting its heritage, translating accumulated financial and social capital into intellectual capital in an "electronic paper" research center at a branch campus of Linkoping University (Svensson, Klofsten, and Etzkowitz, 2012) that has recently generated two spin-off firms (Berger, 2014). The lesson is tight focus in contrast to Newcastle's original Science City plan, with four disparate foci on academic research strengths that neglected the region's strength in heavy engineering (Pearson, 2009).

A relatively small venue may only be able to afford one bet on its future: best make it a big one to make a difference. Although Ashland's initial financial bet was small, a considerable commitment of social capital was transmuted into civic and cultural capitals. Why would a rural town have such a festival, lacking even the faintest link to the Bard such as the fortuitous naming of Stratford, Ontario and Connecticut that inspired two other festivals in his honor? Ashland's tenuous link to Shakespeare was embodied in Angus Bowmer, a drama teacher with a passion for live theatre who inspired an act of civic entrepreneurship.

While the research university capitalizes knowledge that it generates; the teaching university generates entrepreneurship by recombining knowledge that it acquires. A university may provide the 'raw materials' of Shakespeare and electrical engineering to build that platform, just as trees, agriculture and a railway provided the elements for Ashland's previous economic base. New knowledge from the scientific frontier may more readily translate directly into business entrepreneurship, despite translational gaps 
(Qian, Acs and Stough, 2012). Old knowledge, memorialized in textbooks or ensconced in the literary cannon, like Shakespeare, may take a more circuitous route to capitalization. Ashland's renewal demonstrates the potential of the teaching university and the humanities in the triple helix dynamic of economic and social development.

\section{Endnotes}

ahttp://www.interculturalstudies.org/faq.html\#quote

${ }^{b}$ Acknowledgement to Dr. Chunyan Zhou

'A "normal school," an academic format now superseded, was a specialized baccalaureate degree institution offering a range of liberal arts and science subject matter specialties and education training to prepare graduates as elementary and secondary school teachers. The analogous UK institution is the Teacher Training College (TTC). In this paper we refer to the school as SOU or Southern Oregon University that has developed, from its normal school roots, into a liberal arts college and then to its current status as a masters level institution.

${ }^{\mathrm{d}}$ Nevertheless, the Memorial Theatre, that recently celebrated its $75^{\text {th }}$ anniversary, was constructed in 1937 as Stanford's campus performance venue

'It would be decades before the entrepreneurial ethos of Stanford's engineering school spread to the Music Department. Patentable algorithms, synthesizing software and music were licensed to the Yamaha Corporation (Nelson, 2005), and an interdisciplinary field synthesizing computers and music was created in the Music department.

${ }^{\mathrm{f}}$ Letter from M. Bailey to A. Bowmer, 30 September, 1948 Folder 17, Box 2 Series I SC 020 Margery Bailey Papers, Stanford University Archives.

${ }^{g}$ Letter from President Elmo Stevenson to Prof. Margery Bailey, Feburary 27, 1948 Folder 17, Box 2 Series I SC 020 Margery Bailey Papers, Stanford University Archives.

horegon Shakespeare Festival, Archives Division, "Education Department Records, 1947-2011", pp. 4-5.

${ }^{\mathrm{i}}$ www.ashland.or.us/files/SOU_IndustrialClustersReport.pdf last accessed 15 April 2013

'http://lithiaspringsresort.com/welcome.html last accessed 4 April 2013

${ }^{k}$ Oregon Shakespeare Festival, "Oregon Shakespeare Festival State and Local Economic Impact - 2011".

ICase 22 Innovation at Barcelona Innovation District http://sustainablecitiescollective. com/ecpa-urban-planning/27601/case-study-22-barcelona-innovation-district.

${ }^{\mathrm{m}}$ Author interviews with Josep Pique, Director of Arroba 22, 2007, 2010.

\section{Additional file}

Additional file 1: Multilingual abstract in Arabic.

Competing interests

The authors declare that they have no competing interests.

\section{Acknowledgements}

This article draws upon Kaan and Etzkowitz "Power of Cultural Entrepreneurship" Case Study for Project on UniversityBusiness Cooperation in the United States and Canada for the Directorate General for Education and Culture of the

European Commission EAC 02-2010, Framework Service Contract to provide expertise and support for European

Cooperation in Education and Training, Lot 4. 
References

Amisse S, Leroux I, Muller P (2012) Proximities and Logics Underlying Cluster Dynamics: The Case of Ornamental Horticulture Cluster in Maine-et-Loire. Industry and Innovation 19(3):265

Arendt H (1958) The Human Condition. University of Chicago Press, Chicago

Ashland, Oregon Chamber of Commerce (2012) Living and Doing Business Guide. American Chamber of Commerce Executives

Bai M (2013) Thrown for a curve in Rhode Island. New York Times Business Section 1:21

Baine W (2014) New name, new season for Shakespeare Santa Cruz SentinaL March 4

Baker T, Nelson R (2005) Creating Something from Nothing: Resource Construction through Entrepreneurial Bricolage. Administrative Sci Quarterly 50(3):329-366

BBC (2005) "Self-styled king of Hay sells up". 18, August http://news.bbc.co.uk/2/hi/uk_news/wales/mid_/4159106.stm last accessed 14 April 2013

Becker H (1963) Outsiders: Studies in the Sociology of Deviance. The Free Press, New York

Bergek A, Jacobsson S, Carlsson B, Lindmark S, Rickne A (2008) Analyzing the functional dynamics of technological innovation systems: a scheme of analysis. Research Policy 37(3):407-429

Berger C (2014) Incubator Manager. Interview with the Author, Norrköping Science Park, 28 August

Boschma R (2005) Social Capital and Regional Development: an Emprical Analysis of the Third Italy. In R. Boschma and R. Kloosterman (Eds.), Learning From Clusters, 139-168. Springer Netherlands

Boschma R, Fornahl D (2011) Cluster Evolution and a Roadmap for Future Research. Regional Studies 45:10

Bourdieu P (1986) The Forms of Capital. In: Richardson JG (ed) Handbook of Theory and Research for the Sociology of Education. Greenwood Press, New York, pp 241-258

Bowmer A (1975) As I remember, Adam: an autobiography of a festival. Oregon Shakespearean Festival Association, Ashland Breznitz S (2007) From ivory tower to industrial promotion: The development of the biotechnology cluster in New haven, Connecticut. Revue dEconomie Industrielle no 120 (4eme trimester): 115-134

Cantillon R (1775) An Essay on Economic Theory Auburn. Ludwig von Mises Institute, Alabama [1755]

Carayannis E, Campbell D (2009) "Mode 3" and "Quadruple Helix": toward a 21st century fractal innovation ecosystem. Int J Tech Man 46(3/4):201-234

Caro R (1974) The Power Broker. Knopf, New York

Cooper R (1986) The American Shakespeare Theatre: Stratford, 1955-1985 Cranberry. Associated Universities Press, NJ de Tocqueville A (1851) Democracy in America. A.S. Barnes \& Co., New York

Dees G (1998) he Meaning of Social Entrepreneurship. www.caseatduke.org/documents/dees_sedef.pdf last accessed 19 April 2013

DiMaggio P (1982) Cultural Entrepreneurship in $19^{\text {th }}$ century Boston: the creation of an organizational base for high culture in America Media. Culture and Society 4:33-50

DiMaggio P (1988) Interest and agency in institutional theory. In: Zucker L (ed) Institutional patterns and organizations. 3-22. Ballinger, Cambridge, MA

Etzkowitz H (1983) Entrepreneurial Scientists and Entrepreneurial Universities in American Academic Science. Minerva 21(2-3):198-233

Etzkowitz H (2008) The Triple Helix: University-Industry-Government Innovation In Action. Routledge, London

Etzkowitz H, Klofsten M (2005) The Innovating Region: Towards a theory of knowledge based regional development. Research Management 35(3):243-255

Etzkowitz H, Raiken L (1980) Artists Social Movements of the 1960's and 70's: From Protest to Institution. ERIC, Washington DC

Etzkowitz H, Mello J, Almeida M (2005) Towards 'meta-innovation' in Brazil: The evolution of the incubator and the emergence of a triple helix. Research Policy 34(4):411-424

Florida R (2002) The Rise Of The Creative Class: And How It's Transforming Work, Leisure, Community And Everyday Life. Basic Books, New York

Franklin B (1771) Autobiography of Benjamin Franklin. New York, NY, Macmillan, 1901

Garud R, Karnøe P (2001) Path Creation as a process of Mindful Deviation. Lawrence Erlbaum Associates, Dependence and Creation, London

Gould J (1961) The Chautauqua Movement: An Episode in the Continuing American Revolution. State University of New York Press, Albany

Hall P (2004) Creativity, Culture, Knowledge and the City. Built Environment (30):3

Hall P, Soskice D (eds) (2001) Varieties of Capitalism: The Institutional Foundations of Comparative Advantage. Oxford University Press, Oxford

Henton D, Melville J, Walesh K (1997) Grassroots Leaders for a New Economy: How Civic Entrepreneurs Are Building Prosperous Communities. Jossey Bass, San Francisco

Isaacson W (2011) Steve Jobs. Simon and Schuster, New York

Jacobs J (1961) The Death and Life of Great American Cities. Random House, New York

Johnson K (2013) Experiment in Oregon Gives Medicaid Very Local Roots. New York Times 12 A:12

Kotkin J (2013) Richard Florida Concedes the Limits of the Creative Class. http://www.thedailybeast.com/articles/2013/ 03/20/richard-florida-concedes-the-limits-of-the-creative-class.html last accessed 9 April 2013

Lawton SH, Romeo S, Waters R (2013) Entrepreneurial regions: evidence from Oxfordshire and Cambridgeshire in the UK. Soc Sci Info, In Press

Leca N, Battilana J, Boxenbaum E (2008) E. Agency and Institutions: A Review of Institutional Entrepreneurship Harvard Business School. Working Papers 8(96)

Lecuyer C (2007) Making Silicon Valley: Innovation and the Growth of High Tech, 1930-1970. MIT Press, Cambridge

Lee S (2012) The slow death of the Edinburgh Fringe. Monday 30. July http://www.guardian.co.uk/culture/2012/jul/30/ stewart-lee-slow-death-edinburgh-fringe last accessed 10, April 2013

Lee C, Miller W, Hancock M, Rowen H (2000) The Silicon Valley Edge. Stanford University Press, Stanford

Lysgaard $\mathrm{H}$ (2011) The definition of culture in culture-based urban development strategies: antagonisms in the construction of a culture-based development discourse". Int J Cultural Policy 19(1):182-200 
Lysgaard H, Tveiten O (2005) Cultural economy at work in the City of Kristiansand: Cultural policy as incentive for urban regeneration. Al and Society 19:485-499

Margaret M (1964) Continuities in Cultural Evolution. M.W. Books, New York Margulis J (2014) Where It's All About Lunch. New York Times August 3:TR5

Moure N (1998) California Art: 450 Years of Painting \& Other Media. Dustin Publications, Los Angeles

Nelson A (2005) Cacophony or Harmony?: Multivocal Logics and Technology Licensing by the Stanford University

Department of Music. Industrial and Corporate Change 14(1):93-118

Neuberger R (1948) Shakespeare Makes Good in Oregon". New York Times, August 15

Newsletter S (1956). Ashland Studies in Shakespeare, Institute of 'Renaissance Studies' at Ashland". 6(1):1

Onishi N (2013) A Silicon Valley Vision for San Francisco. New York Times, April 18

Pearson A (2009) Science city - just a hi-tech fantasy plan. The Journal Live, Newcastle 30:1

Penska J (2013) A "triple-helix within a triple-helix": A case study of a university-industry-government industry network PhD. Dissertation

Peredo A, McLean M (2006) Social Entrepreneurship: A Critical Review of the Concept. J World Business

Plaza B (2008) On some challenges and conditions for the Guggenheim to be an effective economic re-activator. $J$ Urban and Regional Res 32(2):506-517

Porter M (1998) Clusters and the new economics of competition. Harvard Business Review 76:77-90

Qian H, Acs ZJ, Stough RR (2012) Regional systems of entrepreneurship: the nexus of human capital, knowledge and new firm formation. Journal of Economic Geography, 1-29

Reid R, Schein S (2007) Industrial Clusters in Jackson and Josephine Counties Prepared for: Economic Development Administration. www.pdffiller.com/27774760-sou_industrialclustersreportpdf-Industrial

Reid R, Schein S, Wilson H (2006) "Industrial Clusters in Jackson and Josephine Counties". Department of Commerce Economic Development Administration, U.S

Sack L (2014) Personal Communication 18 April

Schmiedeberg C (2010) Evaluation of Cluster Policy: A Methodological Overview. Evaluation 16(4):389-412

Schumpeter JA (1951) Essays on Economic Topics. Port Washington, N.Y, Kennikat

Sidelsky R (2003) John Maynard Keynes. Macmillan, London

Solzhenitsyn A (1997) The First Circle. Northwestern University Press, Evanston

Svensson P, Klofsten M, Etzkowitz H (2012) A Knowledge-Based Strategy for Renewing a Declining Industrial City: The Norrköping. Way European Planning Studies 20(4):505-525

Weber M, Eisenstadt S (1968) Charisma and Institution Building. University of Chicago Press, Chicago

Zucker L (1977) The Role of Institutionalization in Cultural Persistence. Am Sociological Rev 42(5):726-743

doi:10.1186/s40604-014-0012-z

Cite this article as: Etzkowitz: Making a humanities town: knowledge-infused clusters, civic entrepreneurship and civil society in local innovation systems. Triple Helix 2014 1:12.

\section{Submit your manuscript to a SpringerOpen ${ }^{\circ}$} journal and benefit from:

- Convenient online submission

Rigorous peer review

- Immediate publication on acceptance

- Open access: articles freely available online

- High visibility within the field

Retaining the copyright to your article

Submit your next manuscript at $\boldsymbol{\sim}$ springeropen.com 